\title{
CAPÍTULOXI
}

\section{Eudaimonia, ethos e pathos: um olhar sobre o discurso político no século XX| ${ }^{1}$}

\section{Introdução}

Qualquer homem, em qualquer tempo, persegue a felicidade acima de tudo. Por isso, durante todo o existir, as ações cotidianas impulsionam o agir humano para uma conquista comum: encontrar caminhos para tornar-se alguém que vive bem e contente com suas realizações. Em grego, felicidade se diz eudaimonia ${ }^{2}$, palavra formada a partir dos vocábulos e $u$ (prefixo que significa bom, o bem ou aquilo que é bom) e daemon (deus, semideus ou gênio, intermediário entre os homens e as divindades superiores). O termo também se refere a uma concepção ética da Antiguidade que visava ao alcance da felicidade como finalidade moral. Porfírio (s/d), em tradução livre, entende o termo como "ética da felicidade" ou o "voltar-se para a felicidade". Em latim, felicitas (felicidade) provém de felix (feliz), a partir do grego phyo (produz), fecundo, produtivo.

A ideia de felicidade, na Antiguidade, continha em si um ideal ético que, em nossos dias, empalideceu-se sobremaneira para dar espaço a um conceito mais fluido, pragmático, meramente instrumental, momentâneo e imediatista. Hoje, centenas de livros de autoajuda, por exemplo, tematizam a felicidade e retoricamente instruem os homens sobre como praticar variadas perspectivas do estar confortavelmente no mundo. Normalmente, tais publicações são criadas para um indivíduo, um ser entre outros e, grosso modo, os caminhos indicados são imediatistas e aparentemente alcançáveis: o prazer, a riqueza, as honras, o poder. Outros, poucos, inflamam nos homens uma visão aristotélica de felicidade: a busca do sumo Bem, o melhor dos bens que existe e é objeto de um saber supremo, uma ciência superior às outras ciências: a Política. Nessa perspectiva, o Bem para os seres humanos não seria alcançado individualmente, mas, sim, num plano plural, por toda a coletividade.

1 Este capítulo foi originalmente publicado: MAGALHÃES, Ana Lúcia; FERREIRA, Luiz Antonio. Eudaimonia, ethos e pathos: um olhar sobre o discurso político no século XXI. VERBUM - Cadernos de Pós-Graduação, v. 9, no 1, 2020, p. 166-186.

2 Optamos pela grafia e acentuação dos termos gregos utilizados dentro da Língua Portuguesa. Mantivemos o itálico e eliminamos todos os diacríticos de acentuação, uma vez que a acentuação do grego não obedece aos mesmos critérios da Língua Portuguesa; excetuamos os nomes próprios. (Nota das revisoras) 
Em qualquer tempo, a felicidade sempre foi vista como um impulso humano fundamental e mereceu atenção de vários pensadores que, ao longo da história da humanidade, apregoaram-na como um bem, um hábito e, sobretudo, como uma virtude humana, sempre conquistada e nunca gratuita. No ato retórico, a forma de conceber e disseminar conceitos sobre a felicidade se conforma num conjunto de argumentos culturalmente determinados, que possuem uma história cultural e indicam a direção a tomar para conquistá-la a partir do impacto que causam sobre um indivíduo ou grupo. No plano patético, os argumentos melhores e mais fortes são aqueles que envolvem o auditório e amplificam o que o orador manifesta ao exortar paixões, sentimentos, emoções, crenças e valores. Por isso, como demonstraremos na análise, os argumentos sobre a felicidade no discurso político implicam atitude do auditório.

A atitude é um conceito que envolve processamento racional, cognitivo e, sobretudo afetivo. O discurso político, objeto de nosso estudo neste texto, explora, grandemente, reações atitudinais e moldam gostos e aversões para criar uma analogia com o ser ou não ser feliz em uma comunidade. As atitudes, no discurso político, categorizam experiências valorativas e, assim, amplificam o mundo. Enfim, como a felicidade é o valor fundamental de todo ser humano, um ato retórico bem construído pode provocar atitudes (pathos) no auditório para realçar o que o próprio público percebe, assimila o que ouve de fontes confiáveis (ou supostamente confiáveis) e reeduca ou confirma seus valores culturais. Nesse sentido, a influência de atitudes sobre a percepção e a interpretação sugere a existência de uma estreita relação entre informação e avaliação humana. Ser feliz, sob a perspectiva do discurso político, envolve, sobretudo, valores culturais, crenças individuais e objetivos menos ou mais comunitários. O alcance efetivo dos argumentos patéticos no auditório vai depender, sobremaneira, do gênero retórico escolhido pelo orador no ato retórico, como demonstraremos logo depois da reflexão inicial sobre as concepções de felicidade particular e pública.

\section{Ser Feliz e Estar Feliz: um Plano Político}

De acordo com Olivieri (2012), a referência filosófica mais antiga de que se dispõe sobre o tema "felicidade" é um fragmento de Tales de Mileto (7-6 a.C.), para quem só é feliz aquele que tem corpo são e forte, boa sorte e alma bem formada. Mileto traduz um anseio natural do povo grego mais antigo: a necessidade de ter "boa sorte", pois disso dependia a felicidade. Sorte, nessa perspectiva, era sinônimo de destino, personificado na figura das Moiras, as três mulheres responsáveis por tecer, na roda da fortuna, 
o fio da vida de todos os homens. Como apenas a linguagem precisa é verificável por expressar ideias também precisas, claras e prováveis, o conceito de Mileto sedimenta-se na crença do auditório, ainda que reflita, no processo de articulação do discurso, o propósito do orador e suas suposições sobre o estado atávico do próprio auditório: ter ou não ter um bom destino.

Tempos depois, Sócrates (469-399 a.C.), que tem suas falas propagadas por Platão nos vários Diálogos, fortifica a ideia - especialmente em $A$ República (PLATÃO, 1999) - de que a virtude deve ser o fim maior das ações práticas para que se chegue a um estado de felicidade. A felicidade, nesse caso, não se relaciona apenas à satisfação dos desejos e necessidades do corpo, mas, sim, ao bem da alma que só pode ser atingido por meio de conduta tão justa quanto virtuosa. Estudos contemporâneos, como os de Dinucci (2009), resumem a posição eudaimonica socrática em três princípios: a) busca a própria felicidade em todas as ações racionais; b) procura a felicidade em si própria; c) indaga qualquer ação racional em prol da felicidade. Para Sócrates, então, a felicidade é produto da virtude e da racionalidade. Esse conceito de felicidade, naturalmente, não está ligado ao de prazer ou de dor, mas ao bem e ao mal. Lembremos ainda que, para Sócrates, a prática da filosofia habilita o homem à felicidade, ou seja, a ação humana requer uma relação entre o autoconhecimento, o conhecimento (episteme) e a virtude (arete) para atingir a felicidade (eudaimonia).

Aristóteles (384 a 322 a.C.) também centra a eudaimonia na excelência da ação humana, a mediania, aquela que é virtuosa por ser a justa medida (ARISTÓTELES, 1973). A ação virtuosa se esquiva dos vícios e promove a ação prudente, capaz de levar à felicidade. Nos cinco primeiros capítulos do livro I de Ética a Nicômaco, o estagirita relaciona moral e caráter como condição necessária para a conquista da felicidade, vista como o maior bem desejado pelos homens e o fim último das condutas humanas. O filósofo reflete também sobre a natureza do Bem - "aquilo a que todas as coisas tendem" (ARISTÓTELES, 1973, p.249) - e tem por objeto a Política, cujo estudo é regrado pela Ética, porque todas as ações belas e justas admitem uma imensa variedade de opiniões úteis a um homem que age de acordo com um princípio racional. Sob esse ângulo, agir passionalmente e não ter experiência dos fatos da vida são elementos impeditivos para a plena conquista da felicidade.

Nessa visão teleológica, é preciso determinar qual o fim da natureza humana, ter clareza de como se constitui o bem, o prazer, a virtude, a felicidade e separar, por exemplo, o bem em si mesmo daquilo que é útil. Além disso: 


\begin{abstract}
[...] como a palavra "bem" tem tantos sentidos quantos "ser" (visto que é predicada tanto na categoria de substância, como de Deus e da razão, quanto na de qualidade, isto é, das virtudes; na de qualidade, isto é, daquilo que é moderado; a de relação, isto é, do útil; na de tempo, isto é, da oportunidade apropriada; no espaço, isto é, do lugar apropriado etc.) está claro que o bem não pode ser algo único e universalmente presente, pois se assim fosse não poderia ser predicado em todas as categorias, mas somente numa. (ARISTÓTELES, 1973, p. 253).
\end{abstract}

Como para todas as coisas há um fim, segundo o filósofo, esse fim deve ser o Sumo Bem, aquele que merece ser buscado em si mesmo. O Sumo Bem é absoluto e incondicional, é o desejável em si mesmo e não se relaciona com outra coisa: "falamos dos bens em dois sentidos: uns devem ser bens em si mesmos, e os outros, em relação aos primeiros" (ARISTÓTELES, 1973, p. 253).

O Bem, então, exige um caminho regrado pelo pensamento consciente. Tendo em vista que Aristóteles associa a virtude à felicidade e essa deve ser adquirida pelo homem, é de se pensar que o exercício do meio-termo seja uma forma de conquista da felicidade, o que não seria exatamente tarefa fácil e exigiria esforço filosófico, pois o filósofo é o homem acostumado à busca da contemplação da verdade e somente onde há contemplação se chega à felicidade. E complementa: "nesse sentido o filósofo é o mais feliz dos homens" (ARISTÓTELES, 1973, p. 367). A felicidade verdadeira, então, seria procurada em si mesma, nunca com vistas a outra coisa, ao passo que o prazer, por exemplo, estaria relacionado ao conflito, pois se ligaria ao que cada indivíduo entende como motivo de prazer, alguma espécie de bem acessório e, por isso, por ser derivada de qualquer espécie de prazer desejado, se esgota tão logo tenha sido alcançado. Assim, a felicidade em si mesma, aquela não resultante de qualquer desejo, passa a ser virtuosa e relacionada à sabedoria filosófica, ou seja, não se esgota e ajusta-se à atividade virtuosa.

Para o filósofo, a felicidade não pode ser adquirida pela aprendizagem, pelo hábito ou por adestramento, não é conferida por providência divina ou pelo acaso, uma vez que é produto da virtuosidade, o que há de melhor e deveria ser partilhada pelo maior número de pessoas. Por isso, a felicidade "é o objetivo da vida política", a ciência que dedica o melhor de seus esforços para fazer com que os cidadãos sejam bons e capazes de nobres ações" (ARISTÓTELES, 1973, p. 259).

No plano ético, enfatiza que o homem verdadeiramente político "goza a reputação de haver estudado a virtude acima de todas as coisas, pois deseja fazer com que os seus concidadãos sejam bons e obedientes às leis" (ARISTÓTELES, 1973, p. 263). No plano da essência e da consti- 
tuição retórica, o político deve saber o que diz respeito à alma, exatamente porque precisa tratar das virtudes, divididas em duas espécies: a intelectual e a moral e nenhuma delas nasce com o homem, mas é adquirida pela prática. Se o homem possui, por natureza, a potência, a capacidade de adaptar-se, a virtude, oposta ao que é inato, é adquirida pelo exercício, pelo uso, pelo fazer. Potencialmente, afirma, temos a capacidade da virtude, da justiça e de todos os bens (ou seus contrários), mas somente pelos atos, ações e pelo exercício, nos tornamos verdadeiramente virtuosos. As ações, por sua vez, ligam-se ao agradável e ao desagradável. Se a virtude nem sempre pode ser exercitada por ser difícil, a ciência política, por sua vez, "gira em torno de prazeres e dores. O homem que lhes der bom uso será bom e o que lhes der mau uso será mau" (ARISTÓTELES, 1973, p. 270). Mas o filósofo não deixa de lembrar que a virtude "está associada à alma e possui três espécies de coisas: paixões, faculdades e disposições de caráter” (ARISTÓTELES, 1973, p. 271). As duas primeiras se relacionam à terceira, pois ninguém é louvado ou censurado pelas paixões em geral (cólera, medo, inveja, alegria, ódio, emulação, compaixão), mas por algumas delas e nem pelas faculdades.

O que se ressalta, então, na perspectiva de Aristóteles, é a visão da prática política como conduta virtuosa, derivada de duas formas da própria virtude: a intelectual - que inclui sabedoria filosófica, entendimento e conhecimento prático - e a moral - que se aproxima do julgamento e da temperança. Ainda que a felicidade seja geralmente buscada em si mesma, o homem feliz é aquele que age com retidão e se vale da sabedoria prática (ou sabedoria filosófica) para atingir seus objetivos. Essa divisão da virtude será, como veremos, particularmente interessante no instante da análise do ato retórico de natureza política, pois, além de revelar os conceitos de felicidade dos governantes, realça características muito singulares da constituição do ethos do orador no ato retórico.

As preocupações sobre a felicidade, suas causas e efeitos encontram ecos em todos os tempos. No Tratado da Correção do Intelecto, por exemplo, Espinosa lança algumas luzes sobre o tema felicidade já no primeiro parágrafo:

Desde que a experiência me ensinou ser vão e fútil tudo o que costuma acontecer na vida cotidiana, e tendo eu visto que todas as coisas de que me arreceava ou que temia não continham em si nada de bom nem de mau senão enquanto o ânimo se deixava abalar por elas, resolvi, enfim, indagar se existia algo que fosse o bem verdadeiro e capaz de comunicar-se, e pelo qual unicamente, rejeitado tudo o mais, o ânimo fosse afetado; mais ainda, se existia algo que, achado e adquirido, me desse para sempre o gozo de uma alegria contínua e suprema. (ESPINOSA, 1983, p. 60-61). 
O texto deixa claro que o interesse ético é inteiramente orientado pela busca do bem supremo definido como "o conhecimento da união que a mente tem com toda a Natureza” (ESPINOSA, 1983, p. 63). Refletiu, por extensão, se haveria algo que desse origem à felicidade suprema ou ela seria a junção desses três bens: riqueza, honra e prazer.

Em verdade, tudo aquilo que o vulgo segue não só não traz nenhum remédio para a conservação de nosso ser mas até o impede e frequentemente é causa de morte para aqueles que o possuem e sempre causa de perecimento para os que são possuídos por isso. [...] Mas o amor de uma coisa eterna e infinita alimenta a alma de pura alegria, sem qualquer tristeza, o que se deve desejar bastante e procurar com todas as forças. (ESPINOSA, 1983, p. 62).

O perecível nos afeta com tristeza, uma vez que a felicidade será passageira. Por outro lado, a busca pelo eterno nos traz a real felicidade. Enquanto os prazeres, riquezas e honras em si mesmos são passageiros e causam males, eles podem ser motivo de felicidade se colocados como instrumentos na procura pelo bem supremo, que se encontra na adequação entre corpo, mente e natureza.

\section{Constituição do Ethos e Discurso Político}

Um homem público, sempre que atua em meio às situações polêmicas e conflituosas do existir em sociedade, vale-se de inúmeras competências e habilidades humanas para agir sobre o mundo por meios persuasivos. Ao exercer um ato retórico (a retórica é material, dinâmica, ativa) e exteriorizar uma proposição, oferece ao outro um compromisso de decisão e, por assim proceder, coloca em jogo seu próprio ser social. Quando se mostra publicamente, vincula seu dizer a uma estratégia discursiva ligada à conveniência, geralmente com uma intenção humana que busca atingir a confiança e provocar o fazer-saber para fazer-querer e, por fim, fazer-fazer.

Conforme Ferreira (2019), nesse plano, a inteligência, essa aptidão intelectual singular, traduz-se, indissociavelmente, em vocalidade. É preciso repertório histórico, no âmbito dos processos gerais e comuns, para revelar compreensão do mundo, capacidade de adaptação às mudanças das circunstâncias, competência para resolver problemas sem violência, extrair inferências, raciocinar sobre si e sobre o outro para, enfim, persuadir. Praticar a retórica é, sim, uma arte, mas também um gesto técnico de racionalizar os caminhos em busca de um resultado associativo que se expande para muito além da troca de informações. 
A eficácia retórica se consolida quando o orador consegue imprimir ao dizer o seu poder de influência. Por isso, praticar a retórica é, com o auxílio forte da percepção, entender, pelo intelecto, que "podemos moldar eventos nos cérebros uns dos outros com primorosa precisão" (PINKER, 2004, p. 5). Como verdades e mentiras são conceitos complexos e oscilantes, no ato retórico, razão e emoção convergem para a demonstração do verossímil. Quando há tensividade retórica, o orador, num contexto em que se situa uma questão, precisa persuadir e para realizar esse intento necessita, como afirma Aristóteles (Retórica, I, cap. II, 1998) encontrar as provas de persuasão fornecidas pelo discurso, que são de três espécies: umas residem no caráter moral do orador (ethos); outras, no modo como se dispõe o ouvinte (pathos); e outras, no próprio discurso (logos), por aquilo que demonstra ou parece demonstrar.

Ao longo dos estudos retóricos, muitos pensadores refletiram sobre a potencialidade do ethos no discurso. Isócrates (436-338 a.C.) parece ter sido o primeiro filósofo a se preocupar com o ethos quando comenta, em Elogio a Helena (ISÓCRATES, 1980a), que a originalidade do discurso não é um valor em si e não pode, portanto, ser dissociada da harmonia entre os períodos da sintaxe clara e bem articulada dos elementos acessórios. Para o filósofo, o discurso une elegância, originalidade e clareza; distingue seu enunciador. E a linguagem é o ponto capital que diferencia os homens dos animais, os cidadãos de estilo mais elevado dos que se contentam com o falar cotidiano. A citação de Isócrates "guarde-se contra as acusações mesmo que sejam falsas porque a multidão é ignorante da verdade e olha só a reputação" (Ad Demonicum, 1.17, 380 a.C.) (ISÓCRATES, 1980b) já mostra o cuidado com o ethos quando comenta sobre a imagem do orador. Na obra Contra os Sofistas (ISÓCRATES, 1980c), o filósofo defende a retórica como núcleo essencial de uma formação e ataca aquela meramente formalista e erística praticada pelos sofistas. Combate a filosofia platônica, que julga inapta para a formação ética e política do homem grego. Ao se preocupar com a formação do homem grego como ser ético e político, reforça atenção para com a imagem.

Aristóteles (384-322 a.C.) dedica especial atenção ao ethos do orador. Concorda que o ethos se molda por meio das qualidades morais do orador, mas não é fruto de uma imagem pública, exterior ao discurso. Enquanto em Isócrates tais qualidades morais moldam o discurso, em Aristóteles o discurso constrói o orador. O estagirita, no livro II da Retórica, parte do pressuposto de que o objetivo de toda retórica é obter um julgamento favorável a determinado ponto de vista. Afirma que não basta zelar pelo discurso, é preciso se apresentar perante o auditório de forma a despertar uma disposição favorável. Para o filósofo, o ethos (1) pressupõe o logos (2) e o pathos (3): o segundo, ligado especificamente ao orador, é sua capacidade de convencer por meio do 
conhecimento, sua capacidade argumentativa, sua lógica; o terceiro, associado ao auditório, seria a habilidade de o orador despertar a emoção no auditório, movê-lo pelo sentimento que provoca.

O filósofo pretendia uma techne que visasse a examinar não apenas o que é persuasivo nos indivíduos, mas para este ou aquele tipo de indivíduo. A prova pelo ethos consiste em causar boa impressão por meio da construção dos seus discursos, em fornecer uma imagem de si capaz de convencer o auditório e ganhar sua confiança. Embora o ethos do orador seja preponderante no discurso, não há como separá-lo do pathos, pois os discursos são dirigidos a um auditório. Para isso, é preciso predispor o ouvinte a aderir às ideias e à justificativa fornecida pelo filósofo da retórica é clara:

[...] não se veem as coisas com o mesmo olhar quando se ama e quando se é movido pelo ódio, nem quando se está encolerizado e quando se está calmo; mas tudo se mostra de outra forma ou recebe uma importância bastante diferente. (ARISTÓTELES, s/d, p. 34).

$\mathrm{Na}$ retórica de Cícero (106-43 a.C.), a eloquência funda-se em dois aspectos: a) ético, porque relacionado à conduta do orador; b) patético, visto que busca a adesão pela emoção. Meyer comenta que a retórica de Cícero "nos introduz em um universo de representação sensível onde as simulações do corpo e do discurso têm a sinceridade por condição e a emoção real por efeito" (MEYER, 1994, p. 68). Cícero associa o ethos a manifestações físicas - gestos, tom e intensidade de voz, expressões faciais - que funcionam como reforço à imagem do orador. Essa postura desperta o pathos no auditório, que adere aos valores do orador. Dessa forma, o ethos seria mais do que textual. E importante mencionar que o trabalho de Cícero, publicado na época de ouro do Império Romano, levou os estudiosos romanos a se preocuparem com o estilo, com a finalidade de envolver plenamente o público. A figura do orador ideal - e aqui podemos pensar em ethos ideal - deveria levar em conta o plano moral e intelectual (com sabedoria e virtude), além de também político (relacionado ao Estado) e religioso (o orador seria "divino" e pareceria "quase um deus").

O ethos continua destacado em Quintiliano (35-95), que recupera Isócrates, pois está ligado aos atributos morais (integridade, coragem - ethos), intelectuais (conhecimento e capacidade de raciocínio - logos) e verbais (eloquência-pathos), necessários ao orador (QUINTILIANO, 1936). A retórica volta a ser a arte do bem falar com preocupação moralizadora, ou seja, é construída pela reputação do orador que está mais relacionada ao ethos do que ao pathos e logos. Embora Aristóteles já comente sobre tais características, Quintiliano tem um viés educacional: 
uma vida reta e honrada [...] um cidadão ideal, apto a assumir sua parte na condução dos negócios públicos e particulares, capaz de governar cidades por meio do seu sábio conselho, de estabelecê-las sobre uma fundação segura de boas leis e de aprimorá-las através da administração imparcial da justiça. (QUINTILIANO, 1936, p. 5).

Tais conceitos de retórica perduraram até o século XVI e o ethos ora se baseava na figura do orador (Isócrates, Cícero, Quintiliano), ora no discurso (Aristóteles). Muitos outros estudiosos se ocuparam do ethos e os conceitos atuais não são idênticos aos da retórica antiga, embora guardem semelhanças importantes; a fala não está mais restrita pelos mesmos dispositivos; a retórica, que era disciplina única, explodiu em diversas outras teóricas e práticas ${ }^{3}$, com interesses distintos e captam o ethos de formas diversas: como noção discursiva (constrói-se por meio do discurso, não é uma imagem do orador, exterior à fala); como processo interativo de influência do outro; como noção híbrida (sociodiscursiva), um comportamento julgado socialmente, que não pode ser apreendido fora de uma situação de comunicação precisa, integrada ela mesma em uma conjuntura socio-histórica determinada.

\section{Felicidade e Política}

O tema - presença da eudaimonia -, repensado em nossos tempos, assume configurações singulares: ligado à velocidade trazida pela pós-modernidade, deu origem à "realidade líquida" (BAUMAN, 2007), a um ambiente novo, que cria uma série de estímulos inéditos, sem precedentes se vistas num ângulo de atividades individuais. Em primeiro lugar, porque as organizações sociais não podem mais manter uma mesma forma por muito tempo, pois se desintegram mais rapidamente do que a duração para moldá-las e reorganizá-las; em segundo lugar porque "a separação e iminente divórcio entre poder e política", que agora se afastam na direção de um espaço global, promovem uma fonte de profundas e incontroláveis incertezas. Para Bauman (2007), a falta de poder torna as instituições políticas existentes, assim como suas iniciativas e seus empreendimentos, cada vez menos relevantes para os problemas existenciais dos cidadãos dos Estados-nações e, por essa razão, atraem cada vez menos a atenção destes.

Ao se aprofundar no mundo de incertezas de Bauman, é possível que a sensação inicial seja de medo, injustiça, privações, falta de privacidade - promovida pela globalização. É de se perceber ainda que o bem-estar de um espaço está sempre referenciado à miséria de outro. Uma visão pessimista.

3 Relações Públicas, Comunicação, Comunicação Social etc. (Nota dos autores) 
No entanto, o homem tem sobrevivido às intempéries, às guerras, a diferentes tipos de mudanças, à violência. Um retorno a Platão e Aristóteles mostra que a estrutura fundamental da ética eudaimonica pode ser um caminho. Diversos outros pensadores dedicaram a vida na busca de respostas, com algumas pistas próximas, algumas provas, mas não há espaço, neste texto, para todos.

Para uma análise do que nos falam os autores citados sobre eudaimonia e ethos, escolhemos trechos de discursos proferidos por dois dirigentes de países importantes que, sobre temas semelhantes, mostram escolhas diferentes: a Chanceler Angela Merkel, em discurso pronunciado em 2018, em Marrakesh, discorre sobre a adoção do pacto global para migração segura e o Presidente Donald Trump, em um discurso de campanha em 2016, em Phoenix, Arizona, argumenta sobre a construção de um muro entre o México e os Estados Unidos da América (EUA). Serão tomados alguns trechos, uma vez que os discursos são extensos. A intenção é mostrar se, e de que maneira, a Eudaimonia, o ethos e o pathos estão associados nesses discursos ao que pregam os filósofos estudados. Conforme Aristóteles, agir passionalmente e não ter experiência dos fatos da vida seriam elementos impeditivos para a plena conquista da felicidade. Assim, os discursos são permeados de logos, embora, em certos momentos, uns mais, outros menos, manipulem passionalmente os dados.

Estou muito feliz de estar aqui com vocês, em Marrakech hoje. Gostaria de expressar meus sinceros agradecimentos a nossos anfitriões marroquinos e também às Nações Unidas e a todos os que tornaram essa conferência possível. Hoje é um dia muito importante: estamos, pela primeira vez, adotando um acordo político de migração em nível global. A Assembleia Geral das Nações Unidas estava certa em dar foco a dois temas em 2016 - por um lado, o tópico dos refugiados, a base legal com que a Convenção se posiciona em relação aos refugiados, e por outro lado, o tópico da migração, assunto que afeta milhões de pessoas em vários lugares do mundo. Deve ser feita uma distinção clara entre refugiados e migrantes e essa distinção é particularmente significativa. ${ }^{4}$ (Tradução de Ana Lúcia Magalhães).

A felicidade, no discurso de Angela Merkel, é expressa na primeira frase e é reforçada pelo advérbio "muito". O verbo é "estar" que, no plano semântico, impõe uma condição passageira. Estar feliz não é ser feliz. Um fato, porém, ligado a um acordo político justifica o estar feliz: a criação de um acordo de migração

4 THE FEDERAL CHANCELLOR. Speech by Federal Chancellor Dr Angela Merkel in Marrakech on 10 December 2018. Disponível em: <https://www.un.org/en/conf/migration/assets/pdf/GCM-Statements/ germany.pdf $>$. Acesso em 9 de junho de 2019. 
em nível global. O Bem procurado tem natureza fundamentalmente política e situa o orador como o transmissor de um plano final, legalmente bem-sucedido, que justifica o estado de espírito num contexto em que a polêmica se instaurou em vários momentos anteriores. Em retórica, mostrar evidências é uma forma importante de dar suporte a um apelo e reforçar a credibilidade de quem pratica o ato retórico: anunciar a resolução de uma questão, eminentemente política e altamente retórica, almejada tanto pelo auditório quanto pelo orador. Evidentemente, o discurso se ancora no gênero deliberativo (político) que realça um propósito conveniente ou inconveniente, aponta para o futuro (feliz) a partir do acordo e resolve uma questão política ligada ao estado de espírito dos eleitores. Por virtude da própria oradora, o gênero forense se infiltra no político e demonstra como o acordo que se efetua realça a justiça da ação no presente, a injustiça no passado e coloca o auditório como júri para resolver questões de fato.

$\mathrm{O}$ contexto retórico em que o discurso se situa justifica o tom formal do ato retórico da chanceler, dá precisão à fala e inicia-se o discurso após a saudação preliminar às autoridades, com a descrição do estado de espírito da oradora. Os termos escolhidos mostram um ethos de solidariedade e empatia, ligados ao pathos que desperta no auditório.

A disposição em que os argumentos são postos no texto mostram as intenções persuasivas, que ocorrem por meio das unidades temáticas. Perelman, ao refletir sobre a força dos argumentos e sua relação com a ordem em que aparecem, enumera: "1) a ordem crescente, 2) a decrescente e 3) a nestoriana (meio termo entre as ordens)" (PERELMAN, 1993, p. 151).

Como verificamos, a oradora emprega a ordem decrescente, uma vez que inicia com seu estado de espírito: "estou muito feliz", argumento forte, seguido da ordem nestoriana. $\mathrm{O}$ meio termo, aliás, está relacionado à virtude, conforme concebida por Aristóteles (1973), e essa, à felicidade. Esse estar feliz logo no início do texto é um apelo ao pathos, pois tem intenção de despertar no auditório o sentimento de cumplicidade. Não se trata da felicidade comentada em Protágoras (VLASTOS, 1956), que mostra a virtude como instrumento para atingir a felicidade com coisas prazerosas, mas um sentimento relacionado ao outro:

Estamos adotando um acordo político abrangente sobre migração em nível global pela primeira vez [...] o tema dos refugiados, cuja base jurídica é a Convenção sobre o Estatuto dos Refugiados, e [...] o tema da migração, uma questão que afeta milhões de pessoas em todo o mundo. (Tradução de Ana Lúcia Magalhães).

Uma preocupação mundial com o bem do outro e um acentuado ethos de solidariedade, buscado pelo pathos mostrado no discurso. $\mathrm{O}$ sentimento de felicidade explicitado no início do texto prepara o auditório e é construído nos parágrafos seguintes 
é particularmente apropriado que também consideremos o destino dos muitos milhões de migrantes em todo o mundo e reiteremos nossa conviç̧ão de que os direitos se aplicam a todos os indivíduos em todos os países da Terra. (grifo nosso) [...] hoje estamos adotando este Pacto, que afirma expressamente que o seu foco é uma migração segura, ordenada e regular. [...] Ficou claro, e também faz sentido que esse objetivo só possa ser alcançado por meio da cooperação multilateral. Poderíamos, portanto, dizer que, 70 anos após a adoção da Declaração Internacional dos Direitos Humanos, é hora de voltarmos nossa atenção conjunta para a questão da migração. A migração é uma ocorrência natural e frequente, e é uma coisa boa quando ocorre legalmente. (Tradução de Ana Lúcia Magalhães).

A preocupação com o bem universal, com a aplicação dos direitos a todos os indivíduos da terra, retira do texto possíveis apreensões particulares: reforça um ethos altruísta, voltado ao bem comum. Alicerçada no que diz Aristóteles (1998), ela busca ganhar a confiança de seu auditório pelo pathos.

A oradora fala que a migração "é uma coisa boa quando ocorre legalmente.”. Lembramos Aristóteles para quem o homem verdadeiramente político também "goza a reputação de haver estudado a virtude acima de todas as coisas, pois deseja fazer com que os seus concidadãos sejam bons e obedientes às leis" (ARISTÓTELES, 1973, p. 263).

O termo Terra, associado a todos os indivíduos, tem força retórica, pois não se trata de um vocábulo gasto em discursos (globalização, por exemplo), mas de uma escolha lexical cuidadosa, que constrói um ethos de cooperação. De certa forma e com sutileza, o discurso revela um ethos de poder, poder esse derivado da justeza da causa.

É de se pensar no Sumo Bem comentado por Aristóteles (1973) e no conceito de liberdade, de Espinosa (1973), quando o discurso se refere à Alemanha "como membro da União Europeia. [...] gozamos de liberdade de movimento para o emprego. Esse é um aspecto do nosso mercado único, e isso traz-nos uma maior prosperidade" (THE FEDERAL CHANCELLOR, 2018). A liberdade espinosana está relacionada à ideia do bem supremo. Enquanto o homem for um ser dominado por paixões, não será livre. $\mathrm{O}$ excerto nos conduz à construção de ethos como a do ser que é livre.

No entanto, o texto não deixa de tangenciar o utilitário e nos lembramos de Platão, para quem, além da virtude, do Bem supremo, outros elementos podem constituir a felicidade humana: na Apologia de Sócrates (PLATÃO, 1990), a riqueza e, em Górgias (PLATÃO, 2011), a sabedoria. 
É por isso que a migração laboral na União Europeia é claramente regulamentada, refletindo também os princípios deste pacto. Devido ao seu desenvolvimento demográfico, a Alemanha é um país que no futuro continuará a exigir um maior número de especialistas qualificados, incluindo mais especialistas de países fora da União Europeia. Portanto, temos interesse na migração legal. E o que é do nosso interesse também está sujeito ao nosso direito soberano à autodeterminação. $\mathrm{O}$ Pacto Global afirma especificamente que os Estados-Membros têm o direito soberano de determinar as suas próprias políticas. (Grifos nossos - tradução de Ana Lúcia Magalhães). ${ }^{5}$

O texto de Angela mostra que há também um interesse do país na migração. Aqui aparece um ethos de pessoa que se preocupa com o utilitário. $\mathrm{O}$ excerto mostra não o pensar a eudaimonia socrática, platônica, aristotélica ou espinosana como bem supremo, o ser feliz, ligado ao caráter, uma questão ética, moral e de valores, mas o conceito de felicidade como estar feliz, comentado por esses pensadores em relação aos homens comuns: prazer, honra, riqueza.

A Chanceler aponta perigos associados à migração, o que reforça o aspecto pragmático de seu discurso e um ethos que denota preocupação com problemas e riscos. $\mathrm{O}$ apelo à consciência, à dificuldade das condições de trabalho por ela reconhecidas é, mais uma vez, um apelo ao pathos por meio do logos (são reais a injustiça, o trabalho infantil, o tráfico humano), na intenção de se aproximar do auditório.

No entanto, estamos conscientes de que, mesmo no contexto da migração legal como existe no mundo de hoje, algumas pessoas estão expostas a condições de trabalho extremamente injustas. $\mathrm{O}$ trabalho infantil ainda é uma realidade. Condições de trabalho difíceis são uma realidade. [...] destinado a prevenir e combater a migração ilegal, o tráfico humano. [...] todo indivíduo deve ter documentação adequada. Estamos todos conscientes dos riscos que as pessoas que caem nas mãos de traficantes de seres humanos e contrabandistas estão expostos. (Tradução de Ana Lúcia Magalhães). ${ }^{6}$

O texto da Chanceler continua a expressar um chamamento ao caráter, à busca pela justiça, aos direitos dos indivíduos e a invocar contra as más condições

5 THE FEDERAL CHANCELLOR. Speech by Federal Chancellor Dr Angela Merkel in Marrakech on 10 December 2018. Disponível em: <https://www.un.org/en/conf/migration/assets/pdf/GCM-Statements/ germany.pdf $>$. Acesso em 9 de junho de 2019.

6 THE FEDERAL CHANCELLOR. Speech by Federal Chancellor Dr Angela Merkel in Marrakech on 10 December 2018. Disponível em: <https://www.un.org/en/conf/migration/assets/pdf/GCM-Statements/ germany.pdf $>$. Acesso em 9 de junho de 2019. 
de trabalho, à ilegalidade que conduz ao tráfico humano e aos riscos que os homens correm nas mãos de indivíduos desprovidos de caráter.

É por isso que vale a pena lutar por este Pacto - tanto por causa das muitas pessoas que assim poderão ter uma vida melhor, como por seu compromisso claro com o multilateralismo. Esta é a única maneira de podermos tornar nosso mundo um lugar melhor. A Alemanha está comprometida com essa tarefa. [...] A Alemanha continuará a desempenhar um papel ativo na sua posterior implementação para o benefício das pessoas do nosso planeta. (Tradução de Ana Lúcia Magalhães).

Finaliza o discurso com um convite a que todos se comprometam no sentido de melhorar o mundo para que todas as pessoas se beneficiem, ethos de solidariedade e pragmatismo. Pode-se dizer que todo o discurso se pauta pelos conceitos de eudaimonia conforme Sócrates e Espinosa, uma vez que procura o bem geral do indivíduo e está associado à virtude, conforme mostrada por Aristóteles como caminho do meio, a não ser o trecho que fala do interesse da Alemanha na mão de obra estrangeira. A utilização da primeira pessoa do plural em todo o discurso é, também, uma forte manifestação do pathos.

O discurso do Presidente Trump, proferido em 31 de agosto de 2016, tem início com agradecimentos ao povo e com a descrição de seu estado de espírito: encontra-se feliz por estar em Phoenix. Utiliza da repetição no começo (quatro agradecimentos em quatro frases) e ao longo de todo o texto, como reforço aos argumentos escolhidos. Aqui se delineia um ethos de cumplicidade e o tom indica exteriorização do pathos.

Uau. Obrigado. É muita gente, Phoenix, é muita gente. Muito obrigado. Obrigado, Phoenix. Estou tão feliz por estar de volta ao Arizona. O estado que tem um lugar muito, muito especial no meu coração. Eu amo as pessoas do Arizona e juntos venceremos a Casa Branca em novembro. Agora, você sabe que é aqui que tudo começou para mim. Lembra daquela multidão enorme também? Então, eu disse: vamos nos divertir hoje à noite. Nós estamos indo para o Arizona, $\mathrm{OK}$ ? Isso será um pouco diferente. Este não será um discurso de manifestação, por si só. Em vez disso, vou apresentar uma abordagem política detalhada sobre um dos maiores desafios que o país enfrenta atualmente, a imigração ilegal. Acabei de chegar de uma reunião muito importante e especial com o presidente do México, um homem de quem eu gosto e que respeito muito. $\mathrm{E}$ um homem que realmente ama seu país, o México. E, a propósito, assim como eu sou um homem que ama meu país, os Estados Unidos. [...] E em um governo Trump, vamos criar um novo relacionamento entre nossos dois países, mas será um relacionamento justo. (Tradução de Ana Lúcia Magalhães). ${ }^{7}$

7 THE NEW YORK TIMES. Transcription of Donald Trump's immigration speech, Sept. 1, 2016. Disponível em: <https://www.nytimes.com/2016/09/02/us/politics/transcript-trump-immigration -speech.html>. Acesso em 9 de junho de 2019. 
Percebe-se, de imediato, que o ethos de Trump mostra o conceito de felicidade direcionado a um desejo quase pessoal: "together we are going to win the White House in November.” (juntos venceremos a Casa Branca em novembro). Logo em seguida, coloca o conceito em torno do qual girará seu discurso: uma política sobre a imigração. Enquanto o ethos da Chanceler deixa transparecer preocupação com o bem-estar dos imigrantes e estende seu desejo à Terra, ligado à Eudaimonia aristotélica, o presidente anuncia uma política restritiva.

É interessante que, ao identificar o presidente do México como homem que ama seu país e a si da mesma maneira (que ama os EUA), anuncia um ethos de alguma forma separatista: cada qual em seu espaço próprio. Reforça que os dois estão em conversação - ethos de pessoa solidária - e sustenta que ambos os países ganharão com a política a ser anunciada - enfatiza que será criada uma nova relação entre aqueles dois países e, com a adversativa "mas", apresenta que será uma relação justa. O discurso mostra um ethos de dominação: ele teria o conhecimento e o poder de tomar decisões, o que não aconteceria com o outro presidente.

Outra adversativa mostra que a justiça vai depender da colocação de pessoas do seu conhecimento em postos-chave: "But to fix our immigration system, we must change our leadership in Washington and we must change it quickly. Sadly, sadly there is no other way." (Mas, para consertar nosso sistema de imigração, precisamos mudar nossa liderança em Washington e devemos mudá-la rapidamente. Infelizmente, infelizmente não há outro caminho). Novamente se percebe o ethos de dominação, de quem determina o que precisa ser feito, mesmo que possa desagradar a outros. A escolha lexical pelo advérbio "infelizmente", repetido, deixa perceber que não será uma transição fácil e, segundo o presidente, não há alternativa, ou seja, ele sabe o que precisa ser feito: ethos de dominação, mais uma vez. O pathos é desvendado pelo termo escolhido, que realça possíveis sentimentos (infelizmente).

$\mathrm{Na}$ sequência, a afirmação "a verdade é que nosso sistema de imigração é muito pior do que parece" reforça que o anúncio e as decisões que virão podem não ser aceitos, porém são absolutamente necessários:

Hoje, em um assunto muito complicado e muito difícil, você obterá a verdade. $\mathrm{O}$ problema fundamental do sistema de imigração em nosso país é que ele atende às necessidades de doadores ricos, ativistas políticos e políticos poderosos. [...] Não serve para vocês, o povo americano. Quando os políticos falam sobre a reforma da imigração, geralmente querem dizer o seguinte: anistia, fronteiras abertas, salários mais baixos. A reforma da imigração deve significar algo totalmente diferente. Deve significar aperfeiçoamentos em nossas leis e políticas para melhorar a vida dos cidadãos americanos. (Tradução de Ana Lúcia Magalhães) ${ }^{8}$.

8 THE NEW YORK TIMES. Transcription of Donald Trump's immigration speech, Sept. 1, 2016. Disponível em: <https:/www.nytimes.com/2016/09/02/us/politics/transcript-trump-immigration -speech.html>. Acesso em 9 de junho de 2019. 
Novamente o discurso mostra o ethos de quem se julga conhecedor da verdade, que deve importar apenas servir ao povo americano. Coloca, desta forma, um argumento forte que conclama este povo a se dividir para o bem de si próprio: "deve significar aperfeiçoamentos em nossas leis e políticas para melhorar a vida dos cidadãos americanos". E reforça "são preocupações válidas expressas por cidadãos decentes e patrióticos de todas as classes sociais e de todos os lugares.”. Mais uma vez a presença do pathos para conquistar o auditório. $\mathrm{O}$ que se percebe até o momento é que existe uma preocupação com o país, não global, mas determinada a uma fatia da população, dessa maneira, não se poderia associar a felicidade à eudaimonia socrático-platônica (bem supremo), aristotélica (virtude) ou a espinosana.

A afirmação "temos de estar preparados para falar honestamente e sem medo sobre esses assuntos importantes e sensíveis" deixa transparecer a possibilidade de haver desonestidade e medo anteriormente. $\mathrm{O}$ auditório é conduzido de forma indireta, implícita, a esse raciocínio. Reforça que "incontáveis vidas americanas inocentes foram roubadas porque nossos políticos têm falhado a seu dever de promover a segurança nas fronteiras e fazer com que nossas leis sejam cumpridas." Aqui o orador demonstra, mais uma vez, ethos de preocupação em preservar somente o bem-estar de seus concidadãos, sem pensar no bem universal. O verbo roubar associado à falha dos políticos anteriores transporta o auditório à animosidade. Trump manifesta o conceito instrumental de felicidade voltado ao bem pessoal e com fim específico: preservação do seu país (IRWIN, 1995).

Outros argumentos ao longo do discurso reforçam essa concepção: um jovem de 21 anos foi morto por um imigrante ilegal, membro de gangue. Outra vítima teria sido morta a tiros em uma cidade santuário, e uma senhora de 90 anos, espancada em sua residência. $\mathrm{Na}$ Califórnia, uma veterana da Força Aérea foi estuprada e morta a marteladas e o assassino foi preso várias vezes e nunca deportado. Trump cita um relatório de 2011 para afirmar que imigrantes ilegais teriam cometido 25.000 homicídios, parte deles encarcerada a um custo para os EUA, dinheiro que poderia ser gasto em bolsas de estudo para alunos carentes, por exemplo. Argumentar pelo exemplo é uma forma de angariar credibilidade. O Presidente omite do auditório uma questão fundamental: "O que está sendo medido exemplifica o quê exatamente no universo contextual?". "Qual o tamanho da amostragem para obter esses exemplos?”. De qualquer modo, os exemplos são argumentos fortes e o orador esforça-se por traduzir medidas numéricas em termos familiares ao seu auditório. Os exemplos pretendem mostrar evidências nem tão evidentes, embora o viés patético seja nítido: causar repulsa e fomentar a diferença.

Com essas informações o presidente, no plano retórico, reforça uma questão de valor: a disputa entre o que é bom, desejável e útil e o que é ético ou moral. 
Como o auditório é particular, tem consciência de que obterá mais acordos do que desacordos fundamentais. Ao expor parte dos fatos no logos (fatos), o candidato fortalece a necessidade de impedir a imigração que, segundo ele, é a grande responsável pelos crimes citados. No seu entender, o povo mexicano consiste, em parte substancial, de criminosos, embora não cite literalmente. $\mathrm{O}$ orador conduz o auditório, pelo pathos, a crer na necessidade de construção de um muro físico entre os países para impedir a imigração e conter a criminalidade. Essa é a questão de fato: uma disputa entre as evidências mostradas e o modo como devem ser interpretadas.

Construiremos um grande muro ao longo da fronteira sul. PÚBLICO: Construa o muro! Construa o muro! Construa o muro! E o México pagará pelo muro. Cem por cento. Eles ainda não sabem, mas vão pagar por isso. E eles são ótimas pessoas e grandes líderes, mas vão pagar pelo muro. No primeiro dia, começaremos a trabalhar em um muro impenetrável na fronteira: real, alto, poderoso e bonito. Usaremos a melhor tecnologia, incluindo sensores acima e abaixo do solo, que vão descobrir os túneis. Lembre-se disso, acima e abaixo. Sensores acima e abaixo do solo. Torres, vigilância aérea e mão de obra para complementar o muro, encontrar e deslocar túneis e impedir cartéis criminosos. O México, você sabe disso, trabalhará conosco. Eu realmente acredito nisso. O México trabalhará conosco. Eu absolutamente acredito nisso. $\mathrm{E}$, especialmente, depois de me encontrar com seu maravilhoso presidente hoje. Eu realmente acredito que eles querem resolver esse problema conosco, e tenho certeza que sim. Número dois, vamos acabar com esse negócio de prender e soltar. A gente pega e vai em frente, oh, a gente pega e vai em frente. (Tradução de Ana Lúcia Magalhães). ${ }^{9}$

Trump vale-se de um argumento bem forte em retórica: a criação de inimigos. A presença de um antagonista exacerba as paixões, exalta os ânimos e revoluciona as sensações patéticas. O orador informa não apenas sobre a construção do muro, apoiado entusiasticamente pelo auditório (pathos) desperto, mas diz que o México pagará integralmente pela construção desse meio de separação: mais uma vez o ethos de dominação. Nesse ponto fica clara a política isolacionista, que se distancia do que dizem Aristóteles, Platão e Espinosa. Lembremos que Aristóteles (1973) nos fala que a felicidade está associada à virtude, meio termo entre os extremos (falta e excesso). A posição de Trump é a do excesso: em princípio, todos os mexicanos que desejam ir para os EUA seriam criminosos em potencial, daí a

9 THE NEW YORK TIMES. Transcription of Donald Trump's immigration speech, Sept. 1, 2016. Disponível em: <https://www.nytimes.com/2016/09/02/us/politics/transcript-trump-immigration -speech.html>. Acesso em 9 de junho de 2019. 
necessidade da construção de um muro. "Sob minha administração, qualquer pessoa que cruzar ilegalmente a fronteira será detida até que seja removida de nosso país de volta a seu país de origem.". Nesse ponto, o orador toma a palavra e assume a responsabilidade pelas ações. $\mathrm{O}$ uso da primeira pessoa do singular somado aos verbos "deter" e "remover", fortalecem o ethos de poder construído a partir do pathos que despertam, pois tais verbos estão associados à exclusão: pessoas tratadas como objetos indesejados. É nesse instante que envolve o auditório numa questão de natureza política, aquela que sempre envolve uma linha de ação sobre o que deve ou não ser feito numa circunstância particular:

Mas a polícia sabe quem são essas pessoas. Eles convivem com essas pessoas. Eles são ridicularizados por essas pessoas. Eles não podem fazer nada a respeito dessas pessoas e querem fazer. Eles sabem quem são essas pessoas. No primeiro dia, minha primeira hora no cargo, essas pessoas irão embora. E você pode chamar essas pessoas de deportados, se quiser. A imprensa não gosta desse termo. Você pode chamá-los como diabos você quiser. Eles irão embora. [...] eles vão embora. Eles vão sair. Vão sair rápido. Vamos emitir ordens de prisão para imigrantes ilegais que forem presos por qualquer crime que seja, e eles serão conduzidos para remoção imediata. (Tradução de Ana Lúcia Magalhães). ${ }^{10}$

O orador particulariza para mostrar ao auditório que as ações prometidas e a mudança em si são boas e necessárias. Num gesto retórico bem conhecido, assume a responsabilidade argumentativa: apresenta alguém que está sendo prejudicado pela política atual (uma questão de fato ou de valor), mostra um padrão do que é útil ou prejudicial e previne-se ao obrigar os adversários a suportar o fardo da tréplica ou o ônus de refutação (CAMPBELL; HUXMAN; BURKHOLDER, 2015).

Ao dizer que os policiais sabem quem são essas pessoas, continua a colocar todos os imigrantes como criminosos "qualquer pessoa que cruze ilegalmente a fronteira”. Salienta que os policiais, por exemplo, são achincalhados pelos imigrantes ilegais, sem fazer diferença entre criminosos e pessoas que querem trabalhar naquele país para melhorar de vida, com suas famílias, por exemplo. Afirma que vai expulsar a todos imediatamente. O orador demonstra consciência de que toda afirmação precisa de sustentação, de provas para ser levada em consideração, e quando não são oferecidas, essa afirmação não

10 THE NEW YORK TIMES. Transcription of Donald Trump's immigration speech, Sept. 1, 2016. Disponível em: <https://www.nytimes.com/2016/09/02/us/politics/transcript-trump-immigration -speech.html>. Acesso em 9 de junho de 2019. 
tem valor argumentativo e deve ser desconsiderada em um raciocínio lógico. Por isso, reforça a afirmação primordial, a base de todo o raciocínio e, pelo pathos, intenta sustentar o logos. O discurso expressa novamente o ethos de conhecedor da verdade e a escolha lexical amplia a presença do pathos. Tal afirmação vai contra o conceito de eudaimonia vista como bem comum, supremo bem, virtude, na felicidade como ligação entre os homens.

É possível que o candidato esteja pensando na conquista de honras para si, principalmente a presidência, no entanto, para Espinosa (1973), essas são felicidades passageiras e causam males, a não ser quando colocadas como instrumentos na procura pelo bem supremo, o que não parece ser o caso. Há clara busca de bem específico apenas para uma parcela da humanidade.

\section{Considerações Finais}

As intenções eleitoreiras de Trump (THE NEW YORK TIMES, 2016) associam a felicidade ao bem-estar pessoal e traduzem-nas num discurso que se alicerça no argumento da segregação. Para alcançar a felicidade, segundo o orador, é preciso colocar alguns humanos de lado, separar, isolar, apartar, impor a dissociação física e social de indivíduos e grupos. Para ser feliz, nessa perspectiva, é preciso excluir. A ação retórica combina argumentos baseados numa base aparentemente lógica e na dissociação para lançar um convite explícito e altamente patético: o auditório deve projetar, pelo voto, suas próprias conclusões e, assim, participar emocionado pelo bem da pátria. A retórica do ódio, portanto, assegura o ser feliz. O ódio é o meio para atingir um fim instrumental e oportunista. Seu discurso inflamado, com forte apelo patético, explora o argumento autoritário, do controle e do poder.

Angela Merkel (THE FEDERAL CHANCELLOR, 2018), por sua vez, pauta-se no argumento de congregação. A Chanceler conduz o auditório pelo raciocínio dedutivo, que começa a partir de uma tese e move-se para as ilustrações e possíveis aplicações. Diante de um tema polêmico, centra a felicidade na justiça humana. Retoricamente, explica as implicações econômicas, legais e sociais de uma ação afirmativa em busca da felicidade de todos. Vale-se, pois, do argumento de associação para demonstrar uma preocupação com o bem universal e é enfática ao dizer que o Pacto é "a única maneira de podermos tornar nosso mundo um lugar melhor”. À sua maneira, reforça o estar feliz pela associação dos atos às virtudes humanas: a justiça e a bondade, e pratica um discurso que não contraria as ideias fundamentais dos filósofos aqui elencados para pensar a felicidade. 
Cremos ter respondido, assim, às questões iniciais deste texto. Há, sim, diferença significativa entre ser feliz e estar feliz, uma vez que o ser feliz se liga a uma noção mais abrangente e profunda e o estar feliz configura-se como o sentir em momento específico e possui determinantes. Após a análise, percebe-se que o homem público condiciona diversamente a promoção da felicidade em seus governados: pode pensá-la de maneira individualista e autoritária - o estar feliz - ou de forma plural e ligada à finalidade da vida, a uma visão ética da realidade $-o$ ser feliz.

\section{REFERÊNCIAS}

ARISTÓTELES. Ética a Nicômaco. 7. ed. Tradução Leonel Vallandro e Gerd Bornheim. São Paulo: Abril Cultural, 1973. (Coleção Os Pensadores).

ARISTÓTELES. Retórica. Tradução e notas de Manuel Alexandre Júnior, Paulo Farmhouse Alberto e Abel do Nascimento Pena. Lisboa: Imprensa Nacional - Casa da Moeda, 1998.

ARISTÓTELES. Arte retórica e arte poética. São Paulo, Rio de Janeiro: Ediouro, s/d.

BAUMAN, Zygmunt. Tempos Líquidos. Tradução Carlos Alberto Medeiros. Rio de Janeiro: Zahar Editora, 2007.

CAMPBELL, Karlyn Khors; HUXMAN, Susan Shultz; BURKHOLDER, Thomas R. Atos de retórica - para pensar, falar e escrever criticamente. Tradução da $5^{\mathfrak{a}}$ edição norte-americana por Marilena Santana dos Santos Garcia. São Paulo: Cengage Learning, 2015.

DINUCCI, Aldo Lopes. A relação entre virtude e felicidade em Sócrates. Filosofia Unisinos, São Leopoldo-RS, v. 10, n. 3, p. 254-264, set/dez 2009.

ESPINOSA, Baruch. Tratado da correção do intelecto. Tradução e notas por Carlos Lopes de Mattos. 3a edição. São Paulo: Abril Cultural, 1983. (Coleção Os Pensadores). 
ESPINOSA, Baruch. Ética - demonstrada à maneira dos geometras. Tradução Joaquim de Carvalho, Joaquim Ferreira Gomes e Antônio Simões. São Paulo: Abril Cultural, 1973. (Coleção Os Pensadores).

FERREIRA, Luiz Antonio. Inteligência retórica: ethos. São Paulo: Blucher, 2019.

IRWIN, Terence H. Plato's ethics. New York, Garland, 1995, 536 p.

ISÓCRATES. Helen. Seção 1-10. Tradução e notas de George Norlin. Cambridge, MA: Harvard University Press; Londres, William Heinemann, 1980a. Disponível em: <http://www. perseus.tufts.edu/hopper/text?doc=Perseus\%3Atext\%3A1999.01.0144\%3Aspeech\%3D10>. Acesso em dezembro de 2019.

ISÓCRATES. Ad demonicum et panegyricus. Seção 1.17. Tradução e notas de George Norlin. Cambridge, MA: Harvard University Press; Londres, William Heinemann, 1980b. Disponível em: <http://www.perseus.tufts.edu/hopper/ text?doc=Perseus\%3Atext\%3A1999.01.0144\%3Aspeech\%3D1\%3Asection\%3D17>. Acesso em dezembro de 2019.

ISÓCRATES. Against the sophists, seção 1.13. Tradução e notas de George Norlin. Cambridge, MA: Harvard University Press; Londres, William Heinemann, 1980c. Disponível em: <http://www.perseus.tufts.edu/hopper/ text?doc=Perseus\%3Atext\%3A1999.01.0144\%3Aspeech\%3D13>. Acesso em dezembro de 2019.

MEYER, Michel. As bases da retórica. In: CARRILHO, Manuel Maria (org.). Retórica e comunicação. Tradução Fernando Martinho. Porto, Portugal: Edições ASA, 1994, p. 31-70.

OLIVIERI, Antonio Carlos. Filosofia e felicidade: O que é ser feliz segundo os grandes filósofos do passado e do presente. UOL. Pesquisa Escolar: filosofia (extraída da página 3 de Pedagogia e Comunicação, de 28/11/2012). Disponível em: <https://educacao.uol.com.br/disciplinas/filosofia/filosofia-e-felicidade-o-quee-ser-feliz-segundo-os-grandes-filosofos-do-passado-e-do-presente.htm? $\mathrm{cmpid}=$ copiaecola\&cmpid=copiaecola $>$. Acesso em: 4 de fevereiro de 2020.

PERELMAN, Chaïm. O império retórico: retórica e argumentação. Tradução Fernando Trindade e Rui Alexandre Grácio. Porto: ASA, 1993. 
PINKER, Steven. O instinto da linguagem: como a mente cria a linguagem. Tradução Claudia Berliner. São Paulo: Martins Fontes, 2004.

PLATÃO. Górgias. São Paulo: Perspectiva, 2011.

PLATÃO. Apologia de Sócrates. São Paulo: Martin Claret, 1990.

PLATÃO. Republic (books 1-5). 11. ed. Londres, Harvard University Press, 1999, $535 \mathrm{p}$.

PORFÍRIO, Francisco. Eudaimonia. BOL. Mundo Educação: filosofia. Disponível em: <https://mundoeducacao.bol.uol.com.br/filosofia/eudaimonia.htm>. Acesso em: 15 de março de 2020.

QUINTILIANO, Marcos Fábio. Instituições oratórias. Tradução Jerônymo Soares Barboza. Coimbra, Portugal: Imprensa da Universidade de Coimbra, 1936.

THE FEDERAL CHANCELLOR. Speech by Federal Chancellor Dr Angela Merkel in Marrakech on 10 December 2018. Disponível em: <https:// www.un.org/en/conf/migration/assets/pdf/GCM-Statements/germany.pdf>. Acesso em 9 de junho de 2019.

THE NEW YORK TIMES. Transcription of Donald Trump's immigration speech, Sept. 1, 2016. Disponível em: <https://www.nytimes.com/2016/09/02/us/ politics/transcript-trump-immigration-speech.html>. Acesso em 9 de junho de 2019.

VLASTOS, Gregory. Introduction to Protagoras. In: PLATO. Protagoras. Translation by Benjamin Jowett e Martin Ostwald. New York: Bobbs-Merrill, 1956. 